\title{
BRIEF CONSIDERATOINS REGARDING THE JURIDICAL PROTECTION OF PRIVATE LIFE IN THE REGULATION OF THE NEW ROMANIAN CIVIL CODE
}

\author{
G. V.Sabău
}

\section{Georgeta Valeria Sabău}

Faculty of Law

" Vasile Goldiş" Western University, Arad, Romania

* Correspondesnce: Georgeta Valeria Sabău, "Vasile Goldiş" Western University, B.dl. Revoluţiei nr. 94, Arad, Romania

E-mail: georgetasabau@yahoo.com

\section{Abstract}

This article, entitled Brief Considerations Regarding the Juridical Protection of Private Life in the Regulation of the New Romanian civil Code, examines the new legal regime of how the private life of the person is respected, in connection to the inseparable link between the right to a private life, lato sensu, and its four intrinsic rights - the right to freedom of speech, the right of the person to dignity, the right to a private life and image rights.

The regulation was imperatively necessary, both to complete the framework of the values guaranteed by art. 8 of the European Convention of Human Rights, but also to establish an interference between the concept of private life and personal privacy, in the context of the excessive broadcasting of peoples' private lives.

Key words: the right to a private life, the right to privacy, image rights, the violation of the private life

\section{Introduction}

Assuming that there are minimum protection requirements and they are not treated exhaustively, the rights encompassed by the European Convention for the Protection of Human Rights and Fundamental Liberties ${ }^{1}$, even though most are of a civil or political nature, they are also in a limited number and have precise limitations, when it comes to issues of national security, public safety, the economic interest or the prevention of crime ${ }^{2}$.

Considered to be an important element in ensuring the harmonious development of the individual, the right to a private life has been included among the fundamental rights. It is protected and recognized by the international, European and national legislation. Based on the tripartite division of the human structure, the doctrine ${ }^{3}$ puts the private life in the category of the personality rights, which protect the human as a social being.

\footnotetext{
${ }^{1}$ The Convention for the Protection of Human Rights and Fundamental Liberties, also known as the European Convention of Human Rights, signed on November the $4^{\text {th }}, 1950$, in Rome, entered into force on September the $3^{\text {rd }}$, 1953 and ratified by Romania by the no. 30/1994 Law, regarding the ratification of the Convention for the Protection of Human Rights and Fundamental Liberties and of the additional protocols to this convention, published in the "Official Gazette of Romania", part I, no. 135, March 31" 1994.

${ }^{2}$ M. Udroiu, O. Predescu, Protecţia europeană a drepturilor omului şi procesul penal român. Tratat, C. H. Beck Publishing House, Bucharest, 2008, p. 16-17.

${ }^{3}$ C. Jugastru, Reflecţii asupra noţiunii şi evoluţiei drepturilor personalităţii, in the Yearbook of the „G. Bariţiu” History Institute, Series Humanistica, tom. V, Cluj-Napoca, 2007, p. 329.
} 
The right to a private life is characteristic for the English common-law, and the first sentences regarding the concept of private life were provided by the judge Thomas M. Cooley, in 1888 , enunciated by the collocation the right to be left alone ${ }^{4}$.

Even though the concept of private life, presented by art. $8^{5}$, cannot be precisely defined because of the vast array of situations it encompasses and due to the fact that it is not an immutable ${ }^{6}$ right, according to the European Court of Human Rights, the right to a private life is not exhaustive; it incorporates and guarantees a series of other intrinsic rights on the right to privacy, in the sense of free provision over one's body and therefore, sexual freedom, the right of the individuals to have a home, from a broad point of view, the right to make a family and develop emotional relations amongst its members, the right to live in their home environment, the right to the privacy and confidentiality of their life ${ }^{7}$, of the information related to it (even of a medical nature) and of the private conversations ${ }^{8}$, the person's right to have an image ${ }^{9}$, regardless of the location (public - private) and hence the right to a reputation, the right to a social life in the sense of friendship relations with the peers (to whom he has no secrets), the right to a healthy environment (including no phonic ${ }^{10}$, chemical, radioactive or industrial ${ }^{11}$ pollution).

${ }^{4}$ Th. I. Emerson, The Right of Privacy and Freedom of the Press, „Harvard Civil Rights - Civil Liberties Law
Rewiew”, vol. 14, no. 2, Summer, 1979, Faculty Scholarship Series. Paper 2776. http://digitalcommons.law.yale.edu/fss_papers/2776

${ }^{5}$ Art. 8, paragraph 1 of the European Convention of Human Rights stipulates that Everyone has the right to respect for his private and family life, his home and his correspondence. Paragraph 2, art. 8 of the same convention states that There shall be no interference by a public authority with the exercise of this right except such as is in accordance with the law and is necessary in a democratic society in the interests of national security, public safety or the economic well-being of the country, for the prevention of disorder or crime, for the protection of health or morals, or for the protection of the rights and freedoms of others.

${ }^{6}$ M. G. Losano, Despre drepturi şi despre îndatoriri: încă despre tutela vieţii private, in „Legea italiană în privinţa protecţiei vieţii private", translation by A. Lazăr, translation coordinator and edition editor - M. C. Eremia, All Beck Publishing House, Bucharest, 2004, p. 3.

${ }^{7}$ See ECHR, May $4^{\text {th }}, 2000$ ruling, published in the "Official Gazette of Romania", part I, no. 19 of January $11^{\text {th }}$, 2001, in the Rotaru v. Romania case, paragraph 60, where the Court condemned the Romanian state for the violation of art. 8, in the sense that, the Romanian Intelligence Service owned and used a file containing the personal data of the plaintiff; the Court concluded that the Romanian system of collecting and archiving information does not provide sufficient safeguards against abuses. Please note that all the decisions of the European Court to which we refer in this article are available on www.echr.coe.int.

${ }^{8}$ See ECHR, October $22^{\text {nd }}, 2002$ ruling, in the Taylor-Sabori v. the Great Britain case. paragraphs 16-19; the notion of "correspondence" includes any type of communication between two people, regardless of the technical means used to achieve it. Consequently, art. 8 is also applicable when the police illegally intercept the messages sent to the pager of a person.

${ }^{9}$ See ECHR, June $24^{\text {th }}, 2004$ ruling, in the Von Hannover v. Germany case, paragraphs 76-80. The publishing in the press of the photos which portrayed the princess of Hanover, both alone and in the company of people from her daily life, even in public places, constituted a violation of the Convention's art. 8. Otherwise, see the ECHR's decisions from February the $7^{\text {th }}, 2012$, in the Axel Springer AG. v. Germany case, paragraphs 25-83, and in the Von Hannover v. Germany case (2), paragraphs 53-111, where the Court influenced large parts of the decisions, of the criteria applicable in the case of an existing conflict between the right to freedom of speech and that of respecting the private life, should take into consideration the contribution the published materials had in the case of a public debate, of general interest; they should also take into account the level of fame of the person present in those materials, his or her previous conduct, the method in which the materials were obtained and also their veracity, their content, form and the consequences of their publication, as well as the severity of the penalties imposed on the journalists or publication.

${ }^{10}$ There are a number of decisions where the Court ruled that art. 8 was violated, via phonic pollution; in this sense, see ECHR, February $16^{\text {th }}, 2005$ ruling, in the Moreno Gomez v. Spain case, paragraphs 46-63; ECHR, February $9^{\text {th }}$, 2011 ruling, in the Dees v. Hungary case, paragraphs 15-24; ECHR, November $25^{\text {th }}$, 2010 ruling, in the Milevaet al v. Bulgaria case, paragraphs 73-102; ECHR, November 22 $2^{\text {nd }}, 2011$ ruling, in the Zammit Maepel v. Malta case, paragraphs 30-74; ECHR, February $21^{\text {st }}, 1990$ ruling, in the Powell und Rayner v. Great Britain case, paragraphs $37-$ 46; ECHR, July $8^{\text {th }}, 2003$ ruling, in the Hatton et al v. Great Britain case, paragraphs 84-130.

${ }^{11}$ See ECHR, December $9^{\text {th }}, 2004$ ruling, in the Lopez Ostra v. Spain case, paragraphs 44-58; ECHR, February $19^{\text {th }}$, 1998 ruling, in the Guerra et al v. Italy case, paragraphs 56-60; ECHR, November $30^{\text {th }}$, 2004 ruling, in the Öneryldiz v. Turkey case, paragraphs 158-160; ECHR, November $30^{\text {th }}, 2005$ ruling, in the Fadeyeva v. Russia case, paragraphs 64-134; ECHR, March 26 ${ }^{\text {th }}, 2007$ ruling, in the Giacomelli v. Italy case, paragraphs 68-98. 
In the context of modern individualism, even though it has a complex nature, susceptible to many interpretations, the notion of private life must be understood, in our study, as the right to privacy, both in terms of not being disturbed, harassed or pursued without a valid reason, in the public and private space, as well as in the terms of information or private conversations being confidential and the guaranteeing of personal relations' discretion.

Considered to be the classic framework of the private life's protection, the right to privacy or to the privacy of personal relations ${ }^{12}$ is not to be confused with the right to a private life, because it has a more limited area of freedom and action, where the individual may freely externalize their thoughts, feelings in a designated space, be it with the people with whom they fully trust, or even alone, by themselves, uninfluenced by anyone.

\section{Juridical regime}

This right is rooted in art. 12 of the Universal Declaration of Human Rights ${ }^{13}$, which states that No one shall be subjected to arbitrary interference with his privacy, family, home or correspondence, nor to attacks upon his honor and reputation. Everyone has the right to the protection of the law against such interference or attacks.

The right to have one's private life completely respected is also guaranteed by art. 40, paragraph 2, letter a) of the Convention on the Child's Rights ${ }^{14}$.

In matters of bioethics as well, the respect for the private life is guaranteed by art. 10, paragraph 1 of the Convention for the Protection of Human Rights and the Dignity of the Human Being, in relation to applications in the field of biology and medicine ${ }^{15}$, according to whicheveryone has the right to respect for private life in relation to information about his or her health. The Universal Declaration for Bioethics and Human Rights ${ }^{16}$ supports the same right, in the sense that, the private life and the confidentiality of the personal information of said peoplemust be respected. Where possible, this information must not be used or disclosed for purposes other than the ones they were collected for or for which consent was given, in accordance with the international law, including international human rights law.

Another documents which, in art. 7, guarantees the respect for private and family life, is the European Union's Charter of Fundamental Rights ${ }^{17}$, according to which everyone has the right to have their family and private life respected, along with their home and communication privacy.

The protection of the private life is also stipulated in art. 26, paragraphs 1-2 of the Romanian Constitution $^{18}$, which guarantees the respect of the private and family life, in the sense that the public authorities shall respect and protect the intimate, family and private life. Any natural

\footnotetext{
${ }^{12}$ J. F. Renucci, Tratat de drept european al drepturilor omului, Hamangiu Publishing House, Bucharest, 2009, p. 241.

${ }^{13}$ The Universal Declaration of Human Rights was adopted on December the $10^{\text {th }}, 1948$, by the 217 A Resolution, in the context of the Third Session of the UN General Assembly.

${ }^{14}$ The Convention on the Child's Rights was adopted by the National Assembly of the united Nations, on the $20^{\text {th }}$ of November, 1989, and ratified by Romania by the no. 18/1990 Law, for the ratification of the Convention on the Child's Rights, published in the "Official Gazette of Romania", part I, no. 314 of June $13^{\text {th }}, 2001$.

${ }^{15}$ Also called the Convention on Human Rights and Biomedicine, signed in Oviedo, on April the $4^{\text {th }}, 1997$ and ratified in Romania by the no. 17/2001 Law, regarding the ratification of the European Convention for the Protection of Human Rights and the Dignity of the Human Being, in relation to the Applications in the Field of Biology and Medicine, the Convention on Human Rights and Biomedicine, signed in Oviedo, on April the $4^{\text {th }}, 1997$ and of the Additional Protocol to the European Convention for the Protection of Human Rights and the Dignity of the Human Being, in relation to the Applications in the Field of Biology and Medicine, regarding the banning of human cloning, signed in Paris, on January the $12^{\text {th }}, 1998$, published in the "Official Gazette of Romania", part I, no. 103 of February $28^{\text {th }}, 2001$.

${ }^{16}$ The Universal Declaration on Bioethics and Human Rights, adopted on October the $19^{\text {th }}$, 2005; available on http://www.unesco.org/new/en/social-and-human-sciences/themes/bioethics/bioethics-and-human-rights/

${ }^{17}$ The EU Charter of Fundamental Rights was established by the European Commission, European Parliament and the Council of the European Union, on December $7^{\text {th }}, 2000$, in the European Council of Nice.

${ }^{18}$ The Romanian Constitution of 1991, published in the "Official Gazette of Romania", part I, no. 233 of November $21^{\text {st }}, 1991$, amended and revised by the no. 429/2003 Revision Law, published in the "Official Gazette of Romania", part I, no. 758 of October $29^{\text {th }}, 2003$.
} 
person has the right to freely dispose of himself unless by this he infringes on the rights and freedoms of others, on public order or morals. In art. 27 of the Constitution, the inviolability of the residence and domicile are guaranteed, and in art 28. the confidentiality and secrecy of the correspondence if also guaranteed.

The new Civil Code ${ }^{19}$ guarantees the respect of one's private life and dignity of the human being, in section 3, chapter II of title II, dedicated to the natural person, by evoking four rights, namely the right to freedom of speech, the right to a private life, the right to dignity and one's own image, which all seem to permanently bee in an inevitable relation of competitiveness and complementarity. Therefore, according to art. 71, paragraphs 1-3 every person has the right to respect, for his private life. No one shall be subject to any type of interference in their intimate, private or family life, nor in their residence, domicile or correspondence, without their consent or without respecting the limits set out in art. $75^{20}$. It is also prohibited to use, in any way, the correspondence, manuscripts or other personal documents, as well as other personal information for someone's private life, without their consent or without respecting the limits set out in art. 75.

In conjunction with art. 75 , art. 73 , paragraphs $1-2$ of the same code, guarantees the right to one's own image, in the sense that every person is entitled to their own image. In exercising the right to their own image, they may prohibit or hinder the reproduction, in any manner, of their physical appearance or their voice or, depending on the case, the use of said reproduction.

The specialized literature ${ }^{21}$ attributes the concept of private life a limited meaning, failing to encompass in its area the right to one's own image, even though it includes both the right to one's own physical appearance, as well as the right to the voice of said person who owns the right to reproduce and sell them, which leads us to state that they should not be treated in an isolate manner, because their legislator wished only to highlight their complementarity, through a thorough elaboration of these notions. Even the jurisprudence of the European Court established the inclusion of the right to an image in the area pertaining to the right of respecting the private life, regulated by art. 8 of the Convention.

The right to a private life is protected in the Romanian legislation by special laws as well, among which, the no. 506/2006 Law concerning the processing of personal data and the protection of the private life in the electronic communications sector ${ }^{22}$, the no. 504/2002 Law on broadcasting ${ }^{23}$ and the no. 46/2003 Law on patient rights ${ }^{24}$.

\footnotetext{
${ }^{19}$ The no. 287/2009 Law, regarding the Civil Code, published in the "Official Gazette of Romania", part I, no. 511 of July $24^{\text {th }}, 2009$, amended by the no. 71/2011 Law, published in the "Official Gazette of Romania", part I, no. 409 of June $10^{\text {th }}, 2011$, republished in the "Official Gazette of Romania", part I, no. 505 of July 15", 2012, the last amendment being made by the no. 60/2012 Law, regarding the approval of the no. 79/2011 Government Emergency Ordinance, for the regulation of certain measures necessary for the entry into force of the no. 287/2009 Law, regarding the Civil Code, published in the "Official Gazette of Romania", part I, no. 255 of April 17 $7^{\text {th }}, 2012$.

${ }^{20}$ According to art. 75 of the Civil Code, (1) The prejudices which are allowed by the law or by the international conventions and pacts on human rights, to which Romania is a party, do not constitute a violation of the rights provided for, in this section. (2) The exercise of the constitutional rights and freedoms, in good faith and in compliance with the international pacts and convention to which Romania is a party, does not constitute a violation of the rights provided for, in this section.

${ }^{21}$ Fl. Baias, E. Chelaru, R. Constantinovici, I. Macovei (coordinators), Noul Cod civil, comentariupearticole (art. 12664), C.H. Beck Publishing House, Bucharest, 2012, p. 63.

${ }^{22}$ Published in the "Official Gazette of Romania", part I, no. 1101 of November $25^{\text {th }}, 2004$, amended by the no. 272/2006 Law, which was elaborated to amend art. 7 of the no. 506/2004 Law concerning the processing of personal data and the protection of the private life in the electronic communications sector, published in the "Official Gazette of Romania", part I, no. 576 of July $4^{\text {th }}$, 2006, amended by the no. 298/2008 Law on the retention of the data generated or processed by the providers of electronic communication services destined for the public or of public communication networks, as well as for the amendment of the no. 506/2004 Law concerning the processing of personal data and the protection of the private life in the electronic communications sector, published in the "Official Romanian Gazette", part I, no. 780 of November $21^{\text {st }}, 2008$, amended by the no. 1.258/2009 Decision of the Constitutional Court, regarding the plea of unconstitutionality of the no. 298/2008 Law's provisions, on the retention of the data generated or processed by the providers of electronic communication services destined for the public or of public communication networks, as well as for the amendment of the no. 506/2004 Law concerning the
} 
The same provisions are also supported by the no. 329/2003 Law, regarding the practicing of the private detective profession ${ }^{25}$. It allows the private investigator, when exercising his profession, to carry out investigations on the people, goods, acts, dates and circumstances covered by this activity, without prejudicing the right to a private, family or intimate life, or any other fundamental rights and freedoms ${ }^{26}$.

Unfortunately, over the last years, in Romania, we have been faced with the tabloidization of the written press and audio-video media, which base their increase in rating, number of printed copies or traffic (online), especially on scandalous photos and titles, in order to create a sensational, vulgar image, which violates even the slightest resemblance of journalistic ethic.

By no means does this regulation restrict the journalists' right to freedom of speech; on the contrary, the regulation allows the encroachment of the private life of a person, within certain limits:if it justifies a legitimate interest; if the injured party acted explicitly, with the intent of being seen or heard by the perpetrator; if they capture a crime or bring their contribution to uncovering and proving one, or if they detect acts that endanger a public interest.

These provisions may be violated by any person (for example, the person who is a private investigator, who, under the employment of the jealous wife, uses long-distance interception means to record, on an audio-video support, the husband in the house of his mistress journalists, reporters etc.) or even a legal entity (for example, the audio-video media service provider, the tabloid press).

With an exemplificative title, not a limitative one, and subject to art. 75 of the new Civil Code, the following circumstances can be considered violations of privacy, in the sense of art. 74:

a) entering or remaining in the household without a right, or taking any object from it, without the consent of the one legally occupying it. By household we mean any location destined for the domestic use of the person, namely both their residence and domicile, that are inhabited or the room, namely any building intended to be used as a household; in this respect, one must highlight the intimate (private) nature of the life inside said spaces.

b) It is not necessary for the victim to own the places under surveillance; it suffices if the spaces are used in an actual, private - intimate nature. Moreover, the act can also be performed in public, provided there is direct contact between the speakers, respectively a private conversation between two people or more.

c) the unauthorized interception of a private conversation, committed by any technical means, or knowingly using such an interception. This method involves the perception of sounds, words, noises or of the private conversation of the person, aided by audio technical procedures,

processing of personal data and the protection of the private life in the electronic communications sector, published in the "Official Gazette of Romania", part I, no. 798 of November $23^{\text {rd }}, 2009$, the last amendment and addition being made with the no. 13/2012 Government Emergency Ordinance, published in the "Official Gazette of Romania", part I, no. 277/2012.

${ }^{23}$ Published in the "Official Gazette of Romania", part I, no. 534 of July 22 $2^{\text {nd }}, 2002$, amended numerous times, the last change being made via the no. 19/2011 Emergency Ordinance, regarding certain measures to amend certain normative acts in the electronic communications field, published in the "Official Gazette of Romania", part I, no. 146 of February $28^{\text {th }}, 2011$.

${ }^{24}$ Published in the "Official Gazette of Romania", part I, no. 51 of January 29 ${ }^{\text {th }}, 2003$. According to art. 25, any interference in the private, family life of the patient is forbidden, except for the cases where such an interference positively affects the diagnostic, the treatment or the care provided and only with the consent of the patient. The cases where the patient is a danger to himself or to the public safety are exempted.

${ }^{25}$ Published in the "Official Gazette of Romania", part I, no. 530 of July $23^{\text {rd }}, 2003$.

${ }^{26}$ At the request of individuals or legal entities, they conduct specific investigative activities, relating to:

a) the public conduct and morality of a person;

b) data on the solvency and credibility of a natural or legal person, that is a potential partner in a business;

c) people missing from their homes;

d) goods subject to civil or criminal litigation, estranged with the purpose of prejudicing the interests of one of the parties involved in the proceedings;

e) ensuring protection against the leakage of information from the private life area or that of the activity of business operators who wish to remain anonymous. 
(microphones, regardless of their form, and the device in which it is put) as well as recording the words of private conversation, regardless of how the recording was stored (recorders or other silent recording means). Private conversations can take place both with the presence of the interlocutors, as well as without them, under the form of oral communications, by means of remote transmission.

d) capturing or using the image or voice of a person found in a private area, without their consent. Capturing or recording images consists in gathering, collecting, obtaining, receiving and printing of a person, regardless of the medium used. Currently, in Japan 27, several complaints have been made, regarding the illicit use of smartphones, in the sense that some applications allow pictures to be taken without triggering a beep, so the person being photographed is unaware of what just happened. Moreover, there are applications that allow people to post on the screen of their phone a message or email, whilst the photo is being taken, so that the person concerned does not suspect a thing.

e) The act, of a person of good faith, of photographing or filming the exterior of a building destined to be a residence, household or holiday home of someone, would not be considered a violation of said person's private life, due to the fact that the act does not violate the law, causing no prejudices to the owner of the building.

f) broadcasting images representing the interior of a private area, without the consent of the person lawfully inhabiting it;

g) keeping one's life under observation, by any means, except for the cases provided by the law; in this sense we can speak of the placement of audio and video technical recording means, respectively the mounting and fixing into place of the audio-video interception systems (even outside the private space). In this context, it is essential to be able to define the fine line between the citizen's right "to be left alone" and the state's right to interfere in his private and family life, when it is necessary to gather evidence and to substantiate a criminal charge.

h) the broadcasting of news, debates, investigations or written or audiovisual reports on the intimate, personal or family life, without having the consent of the person in question.

i) the broadcasting of materials that contain images regarding a person under treatment in the medical facilities, as well as of the personal data concerning health issues, diagnostic issues, treatment, circumstances regarding the disease and other various facts, including the result of the autopsy, without the consent of the person in question, and if they are deceased, without the consent of the family or other authorized people;

j) the use, in bad faith, of the name, image, voice or likeness to another person;

$\mathrm{k}$ ) the dissemination or use of the correspondence, manuscripts or other personal documents, including the data regarding the domicile, residence, as well as the telephone numbers of a person or of their family members, without the consent of the person to whom they belong or, where appropriate, have the right to dispose of them. Broadcasting involves popularizing, emitting via radio waves, even the sale of the publication containing information on the private life of the individuals. In reality, broadcasting involves two steps: the presentation, an activity addressed particularly to the public, which consists of describing, showing, expressing or presenting audiovisual information and the transmission, which involves communicating or transmitting information via the media service providers ${ }^{28}$ or a broadcaster ${ }^{29}$.

\footnotetext{
27 For more details see http://www.dailymail.co.uk/sciencetech/article-2081216/New-silent-camera-apps-causeplague-voyeurism-Japan.html

${ }^{28}$ According to the Broadcasting Act, the media service providers means that person or legal entity, charged with the editorial responsibility of choosing the audiovisual content of the audiovisual media service and that determines its organization manner.

${ }^{29}$ By broadcaster we mean the audiovisual service provider in the television program service area and/or radio broadcasting, and by the radio/TV broadcasting service we mean the linear, audiovisual media service provided by the broadcaster, where the programs are broadcast in a continuous sequence, regardless of the technical means used, with a fixed content and timetable, for the simultaneous viewing/listening of/to the programs, based on a program grid, under a different name and identified by a logo, in the case of television, or by a jingle, in the case of the radio.
} 
In order to retain the violation methods of the private life, that we presented, it is imperative that these acts were committed without the consent of the injured party. However, art. 76 of the New Civil Code establishes the presumption of consent, when the one who the information or material refers to, puts them at the disposal of a person or legal entity of which they are aware carries out their activity in the field of public information. In this case, the consent is implied; there is no need of written agreement in this sense.

The violation of the right to a private life and to one's own image triggers the repairing of the damages, according to the civil or contractual tort rules, and if the offense meets the elements of the offense of violating the private life $^{30}$, the provisions of the criminal law also become incidental.

\section{Conclusions}

Even though the European states pay particular attention to the protection of the right to a private life, the acts being incriminated just as offenses punishable under the provisions of penal codes, Romania will have to take example from the experience of these countries, where, until recently, we witnessed a regulatory void in the area.

From what we have presented, we conclude that, four our country, the regulation was absolutely necessary, both to complete the protective framework of the values guaranteed by art. 8 of the European Convention, as well as due to the rapid and concerning growth of the tabloidization process of the written press and audiovisual media, in the context where the experience of the Romanian public life would require the abodement of certain conduct rules in order to respect the legitimate rights and interests of the individuals.

\section{Bibliography:}

1. M. Udroiu, O. Predescu, Protecţia europeană a drepturilor omului şi procesul penal român. Tratat, C. H. Beck Publishing House, Bucharest, 2008

2. C. Jugastru, Reflecţii asupra noţiunii şi evoluţiei drepturilor personalităţii, in the Yearbook of the „G. Bariţiu” History Institute, Series Humanistica, tom. V, Cluj-Napoca, 2007

3. Th. I. Emerson, The Right of Privacy and Freedom of the Press, „Harvard Civil Rights Civil Liberties Law Rewiew", vol. 14, no. 2, Summer, 1979, Faculty Scholarship Series. Paper 2776. http://digitalcommons.law.yale.edu/fss_papers/2776

4. M. G. Losano, Despre drepturi şi despre îndatoriri: încă despre tutela vieţii private, in „Legea italiană în privinţa protecţiei vieţii private”, translation by A. Lazăr, translation coordinator and edition editor - M. C. Eremia, All Beck Publishing House, Bucharest, 2004

5. J. F. Renucci, Tratat de drept european al drepturilor omului, Hamangiu Publishing House, Bucharest, 2009

6. Fl. Baias, E. Chelaru, R. Constantinovici, I. Macovei (coordinators), Noul Cod civil, comentariu pe articole (art. 1-‘ ?ublishing House, Bucharest, 2012

\footnotetext{
${ }^{30}$ In addition to the traditional incriminations, the New Penal Code criminalizes in art. 225, The violation of the private life (chapter IX - Offenses that violate the domicile and the private life) along with two other new crimes (the violation of the professional office and the disclosure of the professional secret), designed to patch-up the regulatory void and to offer answers to the new forms of violation and endangerment of the private life, in general and especially of the intimacy.
} 